\title{
Yield Responses and Nutrient Uptake of Broccoli as Affected by Lime Type and Fertilizer
}

\author{
K.T. Demchak and C.B. Smith ${ }^{2}$ \\ Department of Horticulture, The Pennsylvania State University, University Park, PA 16802 \\ Additional index words. Brassica oleracea var. botrytis, crucifer, calcitic lime, dolomitic lime, nutrition, leaf analysis
}

\begin{abstract}
In a 3-year study with broccoli [Brassica oleracea var. botrytis (L.) Mill. CV. Green Comet], NP or NPK fertilizer at rates of $56 \mathrm{~N}-56 \mathrm{P}-0 \mathrm{~K}, 56 \mathrm{~N}-56 \mathrm{P}-56 \mathrm{~K}$, and $56 \mathrm{~N}-112 \mathrm{P}-56 \mathrm{~K}\left(\mathrm{~kg} \cdot \mathrm{ha}^{-1}\right)$ were banded in plots to which three types of lime had been applied — calcitic, calcitic with $3 \% \mathrm{Mg}$, or dolomitic. Fertilizer and lime controls were included. Previous liming had raised the soil $\mathrm{pH}$ from 5.3 to 7.2-7.4. Effects of lime on yields were greatest when no fertilizer was applied. Dolomitic lime was the most effective, increasing total yield by $49 \%$, terminal weight by $54 \%$, and hastening maturity. Fertilizer effects were most evident when no lime had been applied, with all fertilizer treatments increasing total yield, terminal and plant weight, and hastening maturity. Most changes occurred in the 56N-56POK treatment. Effects of lime when fertilizer was applied and effects of fertilizer when lime had been applied were less consistent. Lime alone, especially types containing $\mathrm{Mg}$, increased leaf $\mathrm{P}$, which generally followed the-same trend as total yield. Calcitic lime increased leaf $\mathrm{Ca}$ and dolomitic lime increased leaf $\mathrm{Mg}$ over other lime treatments. Calcitic lime with $3 \% \mathrm{Mg}$ increased leaf $\mathrm{Ca}$, but not leaf $\mathrm{Mg}$, compared to the check. All lime treatments decreased leaf $\mathrm{Mu}$, $B$, and Zn. Fertilizer treatments usually increased leaf $\mathbf{N}$ and Mn. Phosphorus uptake was increased by either lime or fertilizer application. Regression analysis strongly suggested that $P$ was the element most responsible for yield increases.
\end{abstract}

Growth and yields of vegetable crops are often adversely affected by conditions due to low soil $\mathrm{pH}$. However, crops differ in their degree of sensitivity to these conditions and in their responses to lime and fertilizer applications. In seeking reasons for these differences, Pombo and Smith (1986), working with snapbeans, tomatoes, anti red beets, found that the sensitivity of red beets and, to a lesser extent, tomatoes could not be explained by $\mathrm{Mn}$ toxicity or poor uptake of $\mathrm{Ca}$ or $\mathrm{Mg}$, but suggested that poor P uptake was involved. The sensitivity of broccoli to low soil $\mathrm{pH}$ and the role of lime and fertilizer in its production have not been studied adequately. There has been very little research dealing with lime effects on growth responses as related to nutrient uptake of the cole crops. Cabbage responded very well to liming in a 2-year study where yield was increased by $46 \%$ when calcitic lime with $3 \% \mathrm{Mg}$ was applied at $15.7 \mathrm{t}$-ha1 (Smith et al., 1986). Other research has dealt largely with responses to fertilizer. Broccoli generally has responded to a high level of N. Substantial increases in total yield were obtained by Hipp (1972, 1974) with N at $168 \mathrm{~kg} \cdot \mathrm{ha}^{-1}$ broadcast, by Dufault and Waters (1985) with $\mathrm{N}$ at $224 \mathrm{~kg} \cdot \mathrm{ha}^{-1}$ broadcast in three applications, by Letey et al. (1983) with $\mathrm{N}$ at 270 or $225 \mathrm{~kg} \cdot \mathrm{ha}^{-1}$. in two experiments using banding plus sidedressing or fertigation, by Cutcliffe (1971) with $\mathrm{N}$ at $90 \mathrm{~kg} \cdot \mathrm{ha}^{-1}$, and by Cutcliffe et al. (1968) with banded $\mathrm{N}$ at $175-250 \mathrm{~kg} \cdot \mathrm{ha}^{-1}$. These $\mathrm{N}$ rates either delayed (Cutcliffe et al., 1968) or had no effect on (Dufault and Waters, 1985) maturity and, in one experiment, increased percentage of hollow stem (Hipp, 1974). Increases in total yields from high rates of $\mathrm{N}$ were obtained only when an adequate rate of $\mathrm{P}$ was applied (Cutcliffe et al., 1968). Applied $\mathrm{P}$ at $70 \mathrm{~kg} \cdot \mathrm{ha}^{-1}$ was associated with the highest and most uniform yield where regression analysis was used to determine that

\footnotetext{
Received for publication 6 Nov. 1989. Authorized for publication as paper no. 153 in the Dept. of Horticulture Series and as paper No. 8296 in the Journal Series of the Pennsylvania Agricultural Experiment Station. The cost of publishing this paper was defrayed in part by the payment of page charges. Under postal regulations, this paper therefore must be hereby marked advertisement solely to indicate this fact.

${ }^{1}$ Research Aide in Plant Nutrition.

${ }^{2}$ Professor Emeritus of Plant Nutrition.
}

yield was more dependent on leaf $\mathrm{P}$ than leaf $\mathrm{K}$ (Peck and McDonald, 1986). Few increases in yields from K application have been reported (Peck and McDonald, 1986). Harrison and Bergman (1981) reported that $\mathrm{K}$ was antagonistic to the uptake of $\mathrm{Ca}$ and $\mathrm{Mg}$ by cabbage.

The objectives of this study were to determine effects of lime type and fertilizer treatments on growth responses of broccoli and, through leaf analysis, determine how these responses were related to nutrient uptake.

\section{Materials and Methods}

Lime and fertilizer experiments with 'Green Comet' broccoli were carried out at the Horticultural Research Farm at Rock Springs. Pa. during 1985-1987. The soil type was Hagerstown silt loam (Typic Hapludalf). The statistical design was a split plot with three replications. The location of the plots in the field was changed each year to avoid planting broccoli in the same area in successive years.

Main plots consisted of three lime types-calcitic $(38 \% \mathrm{Ca}$ plus a trace of $\mathrm{Mg}$ ), calcitic $3 \% \mathrm{Mg}$ (a 3 calcitic : 1 dolomitic mixture), or dolomitic $(21 \% \mathrm{Ca}$ and $12 \% \mathrm{Mg})$, plus a control. The three lime types had been applied at $4.5 \mathrm{t} \cdot \mathrm{ha}^{-1}$ in 1972 , 1974, and 1978. They were broadcast evenly over each plot and incorporated with a rotovator. Soil samples were taken in the spring of each year from each lime plot and were analyzed for $\mathrm{pH}, \mathrm{Ca}$, and $\mathrm{Mg}$ (Dahnke, 1988).

Fertilizer treatments, consisting of NP or NPK at $56 \mathrm{~N}-56 \mathrm{P}-$ $\mathrm{OK}, 56 \mathrm{~N}-56 \mathrm{P}-56 \mathrm{~K}$, and $56 \mathrm{~N}-112 \mathrm{P}-56 \mathrm{~K}\left(\mathrm{~kg} \cdot \mathrm{ha}^{-1}\right)$, plus a control, made up the sub-plots. Urea $(46 \% \mathrm{~N})$, triple superphosphate $(20 \% \mathrm{P})$, and muriate of potash $(50 \% \mathrm{~K})$ were the $\mathrm{N}, \mathrm{P}$, and $\mathrm{K}$ sources, respectively. Broccoli was seeded in 128-cell Todd planter flats (Speedling, Sun City, Fla.) in mid-June of each year using a 1 peat $: 1$ vermiculite mixture. Seedlings were fertilized weekly with a complete soluble fertilizer (5 g of Millers $20 \mathrm{~N}-20 \mathrm{P}-20 \mathrm{~K}+$ micronutrients/liter at 1 liter/flat) starting 2 weeks after seeding and were acclimatized in a coldframe. Seedlings were transplanted mechanically into the field in late July in rows $0.9 \mathrm{~m}$ apart with $0.45 \mathrm{~m}$ between plants. The fertilizer treatments were applied in double bands $10 \mathrm{~cm}$ to each 
side of the plants and $10 \mathrm{~cm}$ deep immediately after transplanting, using a tractor-mounted belt planter. Plots consisted of 12 plants, of which the center eight were used for data collection.

Leaf samples, consisting of the newest fully expanded leaf (petiole and blade) from six plants, were selected from each plot $\approx 40$ days after transplanting. They were cleaned by dipping in a detergent solution, followed by a tap water rinse and three successive distilled water rinses, dried at $60 \mathrm{C}$, and ground to pass through a l-mm screen. Samples were analyzed for eight elements: $\mathrm{N}$ using an Autoanalyzer with manual digestion (Isaac and Johnson, 1976) and $\mathrm{P}, \mathrm{K}, \mathrm{Ca}, \mathrm{Mg}, \mathrm{Mn}, \mathrm{B}$, and $\mathrm{Zn}$ through the use of an ICP emission spectrometer (Dahlquist and Knoll, 1978)

Multiple, harvests were made starting $\approx 50$ days after transplanting. Terminal main heads and lateral side-shoots were harvested as they matured to determine total yield. Terminals were counted and weighed, laterals were weighed, and plants were cut at ground level and weighed after harvesting was complete. Effects on maturity were determined by calculating the percentage of terminal yield that was mature at the time of the first harvest (percent early terminal yield).

All growth response and leaf analysis data were subjected to an analysis of variance. Mean separation was determined by the Wailer-Duncan K ratio t test, where $\mathrm{K}=100$ was considered comparable to the 5\% level. All field and leaf analysis data shown are means of 3 years. Regression analysis was used to determine the relationship between leaf elemental concentrations and total yield (SAS, 1985).

\section{Results and Discussion}

Soil analysis. Means of results from 3 years (Table 1) showed that all liming treatments raised the $\mathrm{pH}$ similarly, although slightly more with the calcitic-3\% Mg type. Soil Mg saturation was increased moderately by the calcitic- $3 \% \mathrm{Mg}$ type and markedly by the dolomitic. Soil Ca saturation was increased substantially by the calcitic and calcitic-3\% Mg types and moderately by dolomitic lime.

Growth responses. There were lime $\mathrm{x}$ fertilizer interactions for yield responses (Table 2), but no significant year x lime, year $x$ fertilizer, or year $\mathrm{x}$ lime $\mathrm{x}$ fertilizer interactions.

Effects of lime were greatest when no fertilizer was applied and varied with type. The calcitic type increased only plant weight, while the calcitic-3\% Mg type increased terminal and plant weight and tended to hasten maturity. The dolomitic type, however, increased total yield by $49 \%$, produced larger plants with terminals that were 54\% heavier, and hastened maturity, with more than twice as many terminals ready at first harvest as when no lime was applied.

Similarly, fertilizer effects were most evident when no lime had been applied. All fertilizer treatments increased total yield,

Table 1. Effects of lime type on soil analyses during 1985-1987.

\begin{tabular}{|c|c|c|c|}
\hline \multirow[b]{3}{*}{ Lime type } & \multicolumn{3}{|c|}{ Criterion $^{2}$} \\
\hline & \multirow[b]{2}{*}{$\mathrm{pH}$} & $\mathrm{Mg}$ & $\mathrm{Ca}$ \\
\hline & & \multicolumn{2}{|c|}{$\%$ of saturation } \\
\hline Control & $5.3 \mathrm{c}$ & $5.8 \mathrm{c}$ & $34.2 \mathrm{c}$ \\
\hline Calcitic & $7.2 \mathrm{~b}$ & $6.0 \mathrm{c}$ & $90.5 a$ \\
\hline Calcitic-3\% Mg & $7.4 \mathrm{a}$ & $9.5 \mathrm{~b}$ & $87.1 \mathrm{~b}$ \\
\hline Dolomitic & $7.2 \mathrm{~b}$ & 27.6 & $68.8 \mathrm{c}$ \\
\hline
\end{tabular}

${ }^{7}$ Mean separation within each column by the Wailer-Duncan $\mathrm{K}$ ratio $\mathrm{t}$ test, with $\mathrm{K}=100$. terminal and plant weight, and hastened maturity. The $56 \mathrm{~N}-$ $56 \mathrm{P}-56 \mathrm{~K}$ and $56 \mathrm{~N}-112 \mathrm{P}-56 \mathrm{~K}$ treatments did not result in larger increases in total yield, terminal weight, or hastening of maturity than the $56 \mathrm{~N}-56 \mathrm{P}-0 \mathrm{~K}$ treatment.

Effects of lime when fertilizer was applied and effects of fertilizer when lime had been applied were less consistent. Lime had no effect on yield responses when $56 \mathrm{~N}-56 \mathrm{P}-0 \mathrm{~K}$ or $56 \mathrm{~N}$ 56P-56K fertilizer treatments were applied and few effects when the $56 \mathrm{~N}-112 \mathrm{P}-56 \mathrm{~K}$ fertilizer treatment was applied. When lime had been applied, most fertilizer effects occurred only with the calcitic or calcitic-3\% Mg types, where the $56 \mathrm{~N}-56 \mathrm{P}-56 \mathrm{~K}$ and $56 \mathrm{~N}-112 \mathrm{P}-56 \mathrm{~K}$ fertilizer treatments increased total yield, terminal weight, and usually plant weight, compared to the fertilizer control. However, when the dolomitic type was applied, the only effect fertilizer had was on plant weight, which was increased by all fertilizer treatments.

Leaf analysis. There were significant lime $\mathrm{x}$ fertilizer interactions for leaf $\mathrm{K}$ and $\mathrm{Mn}$ only.

Leaf $\mathrm{N}$ was not affected by lime when results were averaged across all fertilizer treatments (Table 3), but was increased by fertilizer application when results were averaged across all lime treatments, with the greatest increases occurring with the $56 \mathrm{~N}-$ $56 \mathrm{P}-56 \mathrm{~K}$ and $56 \mathrm{~N}-112 \mathrm{P}-56 \mathrm{~K}$ treatments. However, when lime effects were compared in the control fertilizer treatment (data not shown), leaf $\mathrm{N}$ tended to increase with lime application, with values of $4.39 \%, 4.89 \%, 4.86 \%$, and $5.12 \%$ for the control, calcitic, calcitic-3\% Mg, and dolomitic lime applications, respectively. The level reached when only dolomitic lime was applied approached the level achieved by applying the $56 \mathrm{~N}-$ $56 \mathrm{P}-0 \mathrm{~K}$ treatment alone $(5.49 \%)$, indicating that liming, especially with dolomitic lime, and applying the $56 \mathrm{~N}-56 \mathrm{P}-0 \mathrm{~K}$ treatment, had similar effects on leaf $\mathrm{N}$. Leaf $\mathrm{N}$ values among lime treatments were variable when fertilizer was applied.

Leaf $\mathrm{Ca}$ and $\mathrm{Mg}$ were affected differently by the lime types. Leaf $\mathrm{Ca}$ levels, which were related to the calcium content of the lime applied, were increased $32 \%$ by the calcitic lime type and $23 \%$ by the calcitic- $3 \% \mathrm{Mg}$ type, but were not increased significantly by the dolomitic type. The $56 \mathrm{~N}-56 \mathrm{P}-0 \mathrm{~K}$ treatment resulted in higher $\mathrm{Ca}$ levels than any other fertilizer treatment. Leaf $\mathrm{Mg}$ was doubled by the dolomitic type, but was not affected significantly by the calcitic or calcitic-3\% Mg types. Leaf $\mathrm{Mg}$ levels were higher in the $56 \mathrm{~N}-56 \mathrm{P}-0 \mathrm{~K}$ fertilizer treatment than in the $56 \mathrm{~N}-56 \mathrm{P}-56 \mathrm{~K}$ treatment, probably because of an antgonism with the added $\mathrm{K}$. Leaf $\mathrm{B}$ and $\mathrm{Zn}$ were decreased by all lime types, with calcitic being most effective in reducing $\mathrm{Zn}$. The $56 \mathrm{~N}-112 \mathrm{P}-56 \mathrm{~K}$ fertilizer treatment increased leaf $\mathrm{Zn}$ over the control.

Although the lime $\mathrm{x}$ fertilizer interaction was not significant with leaf $\mathrm{P}$, there are some important points that are apparent only when lime $\mathrm{x}$ fertilizer treatment effects are presented (Fig. 1). Leaf $P$ was increased by lime (as much as $38 \%$ with the dolomitic type) when no fertilizer was applied. When fertilizer was applied, lime effects on leaf $P$ were reduced since even the levels in the control lime treatment were increased. An earlier study conducted for 5 years in the same field (Smith, 1984) showed that all lime types, especially dolomitic, increased leaf $\mathrm{P}$ with sweet corn. Broccoli leaf $\mathrm{P}$ was increased by applying fertilizer and increased most by the $56 \mathrm{~N}-112 \mathrm{P}-56 \mathrm{~K}$ rate across all lime treatments. The $56 \mathrm{~N}-56 \mathrm{P}-56 \mathrm{~K}$ rate increased sweet corn leaf $\mathrm{P}$ further than the $56 \mathrm{~N}-56 \mathrm{P}-0 \mathrm{~K}$ rate only when the calcitic $-3 \% \mathrm{Mg}$ or dolomitic lime types were applied.

Broccoli leaf $\mathrm{K}$ was decreased by all lime types when either no fertilizer or the $56 \mathrm{~N}-56 \mathrm{P}-56 \mathrm{~K}$ fertilizer rate was applied, 
Table 2. Lime type and fertilizer effects on growth responses of 'Green Comet' broccoli (1985-1987).

\begin{tabular}{|c|c|c|c|c|}
\hline \multirow[b]{2}{*}{ Lime type } & \multicolumn{4}{|c|}{ Fertilizer treatment } \\
\hline & ON-OP-OK & $56 \mathrm{~N}-56 \mathrm{P}-0 \mathrm{~K}$ & $56 \mathrm{~N}-56 \mathrm{P}-56 \mathrm{~K}$ & $56 \mathrm{~N}-112 \mathrm{P}-56 \mathrm{~K}$ \\
\hline & \multicolumn{4}{|c|}{ Total yield $\left(t \cdot h a^{-1}\right)$} \\
\hline Control & $3.79 \mathrm{Bb}^{\mathrm{z}}$ & $5.24 \mathrm{~A} \mathrm{a}$ & $6.03 \mathrm{Aa}$ & $5.36 \mathrm{Ac}$ \\
\hline Calcitic & $4.55 \mathrm{Bb}$ & $5.49 \mathrm{ABa}$ & $6.07 \mathrm{Aa}$ & $5.87 \mathrm{Abc}$ \\
\hline Calcitic-3\% Mg & $4.64 \mathrm{Cb}$ & $5.49 \mathrm{BCa}$ & $6.41 \mathrm{ABa}$ & $7.17 \mathrm{Aa}$ \\
\hline \multirow[t]{2}{*}{ Dolomitic } & $5.65 \mathrm{Aa}$ & $6.37 \mathrm{Aa}$ & $5.94 \mathrm{Aa}$ & $6.50 \mathrm{Aab}$ \\
\hline & \multicolumn{4}{|c|}{ Terminal head wt (g/plant) } \\
\hline Control & $104 \mathrm{Bc}$ & $150 \mathrm{Aa}$ & $163 \mathrm{Aa}$ & $140 \mathrm{Ab}$ \\
\hline Calcitic & $123 \mathrm{Bbc}$ & $148 \mathrm{ABa}$ & 159 Аа & $158 \mathrm{Ab}$ \\
\hline Calcitic-3\% Mg & $138 \mathrm{Cab}$ & $154 \mathrm{BCa}$ & $187 \mathrm{ABa}$ & $200 \mathrm{Aa}$ \\
\hline \multirow[t]{2}{*}{ Dolomitic } & $160 \mathrm{Aa}$ & $179 \mathrm{Aa}$ & $156 \mathrm{Aa}$ & $172 \mathrm{Aab}$ \\
\hline & \multicolumn{4}{|c|}{ Plant wt (kg/plant) } \\
\hline Control & $0.51 \mathrm{Cb}$ & $0.75 \mathrm{Ba}$ & $0.94 \mathrm{Aa}$ & $0.82 \mathrm{ABb}$ \\
\hline Calcitic & $0.73 \mathrm{Ca}$ & $0.86 \mathrm{Ba}$ & $0.97 \mathrm{Aa}$ & $0.99 \mathrm{Aa}$ \\
\hline Calcitic-3\% Mg & $0.75 \mathrm{Ba}$ & $0.83 \mathrm{ABa}$ & $1.04 \mathrm{ABa}$ & $1.07 \mathrm{Aa}$ \\
\hline \multirow[t]{2}{*}{ Dolomitic } & $0.71 \mathrm{Ba}$ & $0.95 \mathrm{Aa}$ & $0.97 \mathrm{Aa}$ & $1.01 \mathrm{Aa}$ \\
\hline & \multicolumn{4}{|c|}{ Early terminal yield $(\%)$} \\
\hline Control & $43.1 \mathrm{Bb}$ & $73.6 \mathrm{Aa}$ & $82.0 \mathrm{Aa}$ & $70.6 \mathrm{Aa}$ \\
\hline Calcitic & $51.0 \mathrm{Ab}$ & $77.2 \mathrm{Aa}$ & $77.4 \mathrm{Aa}$ & $75.9 \mathrm{Aa}$ \\
\hline Calcitic-3\% Mg & $69.3 \mathrm{Aab}$ & $75.5 \mathrm{Aa}$ & $70.0 \mathrm{Aa}$ & $77.3 \mathrm{Aa}$ \\
\hline Dolomitic & $89.6 \mathrm{Aa}$ & $88.3 \mathrm{Aa}$ & $82.4 \mathrm{Aa}$ & $86.7 \mathrm{Aa}$ \\
\hline
\end{tabular}

${ }^{2}$ Mean separation within each treatment for each variable by the Wailer-Duncan $\mathrm{K}$ ratio $\mathrm{t}$ test, with $\mathrm{K}=100$. Uppercase letters denote fertilizer treatment effects. Lowercase letters denote lime type effects.

Table 3. Lime type and fertilizer effects on leaf analyses of 'Green Comet' broccoli (1985-1987).

\begin{tabular}{|c|c|c|c|c|}
\hline \multirow[b]{2}{*}{ Treatment } & \multicolumn{3}{|c|}{ Element $^{2}(\%)$} & Element $^{2}\left(\mu \mathrm{g} \cdot \mathrm{g}^{-1}\right)$ \\
\hline & $\mathrm{N}$ & $\mathrm{Ca}$ & $\mathrm{Mg}$ & $\mathrm{Zn}$ \\
\hline \multicolumn{5}{|l|}{ Lime type } \\
\hline Control & 5.43 & a $2.14 \mathrm{c}$ & $0.235 \mathrm{~b}$ & $41.0 \mathrm{a}$ \\
\hline Calcitic & 5.44 & a 2.83 a & $0.224 \mathrm{~b}$ & 15.8 b $24.6 \mathrm{C}$ \\
\hline Calcitic-3\% Mg & 5.51 & a $2.63 \mathrm{~b}$ & $0.265 \mathrm{~b}$ & 16.4 b $27.2 \mathrm{~b}$ \\
\hline Dolomitic & 5.55 & a $2.19 \mathrm{c}$ & 0.473 a & 15.9 b 28.7 b \\
\hline \multicolumn{5}{|l|}{ Fertilizer rate } \\
\hline ON-OP-0K & 4.81 & c 2.44 b & $0.295 \mathrm{ab}$ & 17.4 a $28.9 \mathrm{~b}$ \\
\hline $56 \mathrm{~N}-56 \mathrm{P}-0 \mathrm{~K}$ & 5.45 & b $\quad 2.59$ a & a 0.313 a & $16.9 \mathrm{ab} \quad 30.1 \mathrm{ab}$ \\
\hline $56 \mathrm{~N}-56 \mathrm{P}-56 \mathrm{~K}$ & 5.80 & a $2.40 \mathrm{~b}$ & b $0.290 \mathrm{~b}$ & 15.9 b $30.3 \mathrm{ab}$ \\
\hline $56 \mathrm{~N}-112 \mathrm{P}-56 \mathrm{~K}$ & 5.87 & a $2.37 \mathrm{~b}$ & b $0.299 \mathrm{ab}$ & 18.2 a $33.3 \mathrm{a}$ \\
\hline
\end{tabular}

${ }^{2}$ Mean separation within each lime type and each fertilizer treatment by the Wailer-Duncan $\mathrm{K}$ ratio $t$ test, with $\mathrm{K}=100$.

but was not affected by lime when the $56 \mathrm{~N}-56 \mathrm{P}-0 \mathrm{~K}$ or $56 \mathrm{~N}$ 112P-56K fertilizer treatments were applied (data not shown). Leaf $\mathrm{K}$ was decreased by the $56 \mathrm{~N}-56 \mathrm{P}-0 \mathrm{~K}$ fertilizer rate with all lime types, except the calcitic-3\% Mg type, which was probably a dilution effect because more growth occurred without supplying $\mathrm{K}$.

Leaf Mn (Fig. 2) was related to the effectiveness of lime in reducing and fertilizer in increasing soil acidity. All three lime types reduced leaf Mn markedly, with proportionately greater reductions occurring when fertilizer was applied. Concurrently, leaf $\mathrm{Mn}$ usually increased when the $56 \mathrm{~N}-56 \mathrm{P}-0 \mathrm{~K}$ treatment was applied, with the largest increases occurring when no lime was applied. Addition of K usually increased leaf $\mathrm{Mn}$ further, which was probably due to the chloride contained in the KCI source (Palaniyandi and Smith, 1978).

Regression analysis was used to determine the relationship between leaf concentration and total yield. Each element was

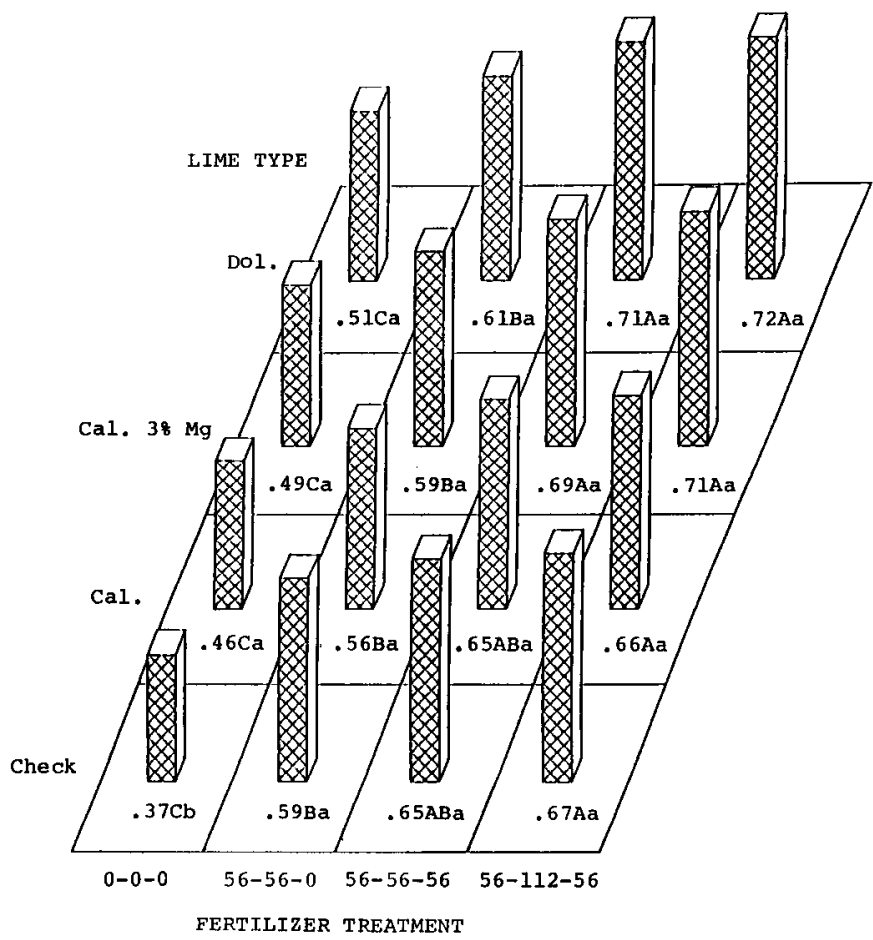

Fig. 1. Lime type and fertilizer treatment $\left(\mathrm{kg} \cdot \mathrm{ha}^{-1}\right.$ of $\mathrm{N}, \mathrm{P}$, and $\left.\mathrm{K}\right)$ effects on leaf P (\%) of 'Green Comet' broccoli (1985-1987). Mean separation with each lime type or fertilizer treatment by the WallerDuncan $\mathrm{K}$ ratio $\mathrm{t}$ test, with $\mathrm{K}=100$. Uppercase letters denote fertilizer treatment effects. Lowercase letters denote lime type effects.

regressed against total yield, being tested for both linear and quadratic fits. In general, over the range of yields and concen- 


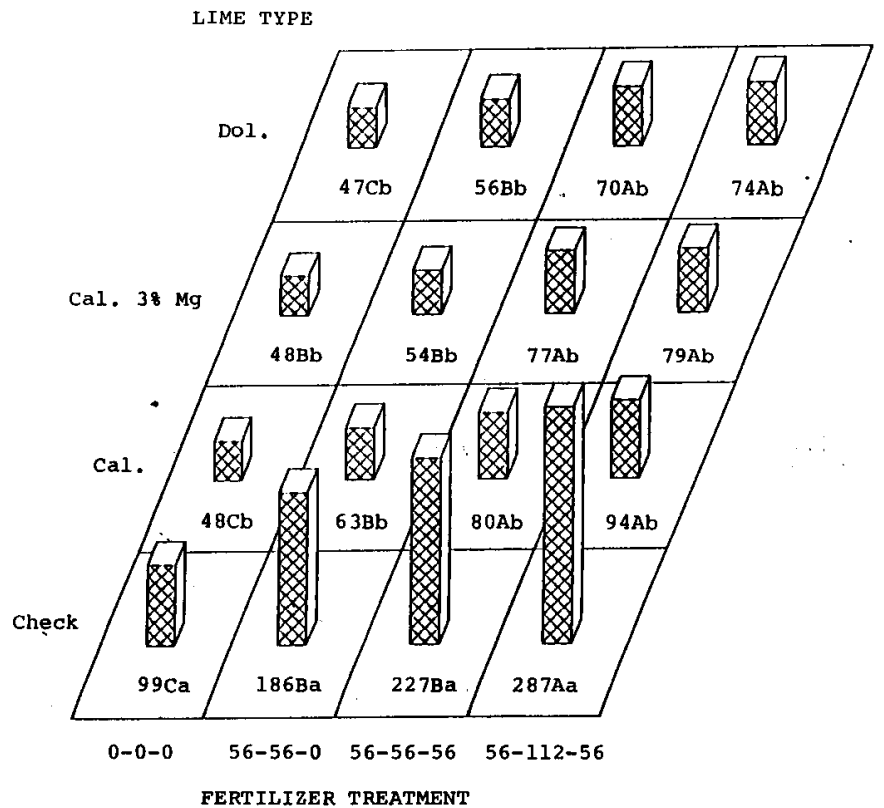

Fig. 2. Lime type and fertilizer treatment $\left(\mathrm{kg} \cdot \mathrm{ha}^{-1}\right.$ of $\mathrm{N}, \mathrm{P}$, and $\left.\mathrm{K}\right)$ effects on leaf Mn ( $\left.\mu \mathrm{g} \cdot \mathrm{g}^{-1}\right)$ of 'Green Comet' broccoli (1985-1987). Mean separation with each lime type or fertilizer treatments by the Wailer-Duncan $\mathrm{K}$ ratio $t$ test, with $\mathrm{K}=100$. Uppercase letters denote fertilizer treatment effects. Lowercase letters denote lime type effects.

trations encountered here, $r^{2}$ values were slightly higher for linear models. When all treatments were included in a simple linear analysis with each element, only $\mathrm{N}$ and $\mathrm{P}$ were significantly related to yield in all three years, with no consistency found with any other elements. Leaf $\mathrm{Mg}$ was not related to total yield, though it was increased by dolomitic lime to a greater extent than was leaf $\mathrm{P}$, and tended to be increased by the $56 \mathrm{~N}$ $56 \mathrm{P}-0 \mathrm{~K}$ fertilizer treatment. Leaf Mn was not closely related to yield increases, being decreased by dolomitic lime alone and increased by the $56 \mathrm{~N}-56 \mathrm{P}-0 \mathrm{~K}$ fertilizer treatment alone. The same analyses were run, including treatments where fertilizer was applied without lime, or lime types were applied without fertilizer. There was little consistency found when only fertilizer was applied. However, when only lime treatments were included, P was the only element related to yield increases. Simple linear regresion equations when only lime was applied and when $\mathrm{N}$ or $\mathrm{P}$ were included as independent variables were:

$$
\begin{array}{r}
\text { 1985: Total yield }=0.239+0.366 \mathrm{~N} r^{2}=0.11 \mathrm{NS} \\
=0.355+4.69 \mathrm{P} r^{2}=0.44 * \\
\begin{aligned}
\text { 1986: Total yield } & =0.108+0.537 \mathrm{~N} r^{2}=0.24 \mathrm{NS} \\
= & 0.174+7.04 \mathrm{P} r^{2}=0.36 *
\end{aligned} \\
\begin{aligned}
\text { 1987: Total yield }=0.536+0.243 \mathrm{~N} r^{2}=0.23 \mathrm{NS} \\
=0.624+1.69 \mathrm{P} r^{2}=0.33 *
\end{aligned}
\end{array}
$$

In this study and others, under low $\mathrm{pH}$ conditions, lime and fertilizer have substituted for each other in increasing yields.
Here, both liming with the dolomitic type and application of fertilizer increased yield, with much of the increase occurring with the $56 \mathrm{~N}-56 \mathrm{P}-0 \mathrm{~K}$ rate. Dolomitic lime had a similar nutritional effect to fertilizer application. Results from this study strongly suggest that increased $\mathrm{P}$ availability was the factor most responsible for the increases in yield, not increased $\mathrm{N}$ or $\mathrm{Mg}$, or decreased $\mathrm{Mn}$, availability. This result would explain the fact that fertilizer substituted for lime, and lime for fertilizer, in increasing yields.

\section{Literature Cited}

Cutcliffe, J. A., D.C. Munro, and D.C. MacKay. 1968. Effect of nitrogen, phosphorus, potassium, and manure on terminal, lateral, and total yields and maturity of broccoli. Can. J. Plant Sci. 48(5):439446.

Cutcliffe, J.A. 1971. Effects of plant population, nitrogen, and harvest date on yield and maturity of single-harvested broccoli. HortScience 6(5):482-484.

Dahlquist, R.L. and J.W. Knoll. 1978. Inductively coupled plasmaatomic emission spectrometer: analysis of biological materials and major, trace and ultra-trace elements. Applied Spectrosc. 39(1): 129.

Dahnke, W.C. 1988. Recommended chemical soil test procedures. North Dakota Agr. Expt. Sta. Bul. 499:1-37.

Dufault, R.J. and L. Waters, Jr. 1985. Interaction of nitrogen fertility and plant populations on transplanted broccoli and cauliflower yields. HortScience 20(1):127-128.

Harrison, H.C. and E.L. Bergman. 1981. Calcium, magnesium, and potassium interrelationships affecting cabbage production. J. Amer. Soc. Hort. Sci. 106(4):500-503.

Hipp, B.W. 1972. Influence of nitrogen and phosphorus on yield and chemical composition of broccoli. J. Rio Grande Hort. Sot. 26:6872.

Hipp, B.W. 1974. Influence of nitrogen and maturity rate on hollow stem in broccoli. HortScience 9(1):68-69.

Isaac, R.A. and W.C. Johnson. 1976. Determination of total nitrogen in plant tissue using a block digestor. J. Assn. Offic. Agr. Chem. 50:98-100.

Letey, J., W.M. Jarrell, N. Valoras, and R. Beverly. 1983. Fertilizer application and irrigation management of broccoli production and fertilizer use efficiency. Agron. J. 75:502-507.

Palaniyandi, R. and C.B. Smith. 1978. Growth and nutrient interrelationships in snap beans as affected by several sources of potassium and magnesium. J. Amer. Soc. Hort. Sci. 103(1):109-113.

Peck, N.H. and G.E. MacDonald. 1986. Cauliflower, broccoli, and brussels sprouts responses to Concentrated superphosphate and potassium chloride fertilization. J. Amer. Soc. Hort. Sci. 111(2): 195201.

Pombo, G.I. and C.B. Smith. 1986. Growth and nutrient interrelationships of three vegetable crops with different sensitivities to soil $\mathrm{pH}$ as affected by lime and fertilizer treatments. Commun. Soil Sci. Plant Anal. 17(3):353-368.

SAS Institute, Inc. 1985. SAS user's guide: Statistics, Version 5 Edition. SAS Institute, Inc., Cary, N.C.

Smith, C.B. 1984. Sweet corn growth responses and leaf concentrations as affected by lime types and fertilizer treatments in a 5-year study. J. Amer. Soc. Hort. Sci. 109(4):572-577.

Smith, C. B., K.T. Demchak, and P.A. Ferretti. 1986. Effects of lime type on yields and leaf concentrations of several vegetable crops as related to soil test levels. J. Amer. Soc. Hort. Sci. 111(6):837-840. 